\title{
The Spiders of East Bay, Southampton Island, Nunavut, Canada
}

\author{
J.R. PICKAVANCE ${ }^{1}$
}

\author{
(Received 30 January 2006; accepted in revised form 17 March 2006)
}

\begin{abstract}
In 2000 and 2001, 22816 spiders were caught in pitfall traps in East Bay Migratory Bird Sanctuary, Southampton Island, Nunavut, Canada. Of these, 18711 were adults of 18 species, 4 lycosids and 14 linyphiids, with 2 of the linyphiids unknown. Six habitats in the study area (gravel ridge, dry heath, scrub willow, sedge meadow, moss carpet, and intertidal zone) are described, and habitat preferences of each species are presented. When compared to five other Canadian Arctic spider communities, the community reported here fits the general pattern of reduction in families and species with increasing latitude, and demonstrates both the patchiness of Arctic spider distribution and the difficulties of comparing habitat preferences.
\end{abstract}

Key words: Arctic, Southampton Island, Araneae, Lycosidae, Linyphiidae, patchiness, habitats

RÉSUMÉ. En 2000 et 2001, 22816 araignées ont été attrapées dans des pièges à fosses du Refuge d'oiseaux migrateurs de la baie Est, dans l'île Southampton, au Nunavut, au Canada. De ce nombre, 18711 étaient des adultes de 18 espèces différentes, soit quatre araignées-loups et 14 linyphies, dont deux des linyphies étaient inconnues. Six habitats visés par l'étude (pente en gravier, bruyère sèche, broussaille de saule, cariçaie, tapis de mousse et zone intertidale) sont décrits. Les préférences de chacune des espèces pour ce qui est des habitats sont également présentées. Comparativement à cinq autres communautés d'araignées de l'Arctique canadien, la communauté dont il est question ici cadre avec la tendance générale de réduction des familles et des espèces plus la latitude augmente, et démontre à la fois l'inégalité de la répartition d'araignées de l'Arctique et les difficultés de comparaison des préférences en matière d'habitat.

Mots clés : Arctique, île Southampton, Araneae, Lycosidae, Linyphiidae, inégalité, habitats

Traduit pour la revue Arctic par Nicole Giguère.

\section{INTRODUCTION}

The Arctic Palaearctic spiders are relatively well known, both from reports of spider communities in defined areas (e.g., Spitsbergen: Koponen, 1980; Finland: Koponen, 1975, 1977; Polar Urals: Tanasevitch, 1985 and Koponen et al., 1998; Yakutia, Siberia: Marusik et al., 2004) and from taxonomic studies of groups (e.g., linyphiids of the Bolshezemelskaya tundra and Polar Urals: Tanasevitch, 1982, 1983, 1984; Ceraticelus, Islandiana, and Collinsia from Siberia and the (then) Soviet Far East: Eskov, 1987, 1989; and Oreoneta: Saaristo and Marusik, 2004).

The Arctic Nearctic spider fauna is less well known except in Greenland, where historical connections to Europe have resulted in a well-documented spider fauna (e.g., Larsen and Scharff, 2003). Some parts of Canada where the spider fauna has been reported encompass Arctic areas, e.g., the Yukon (Dondale et al., 1997), Manitoba (Aitchison-Benell and Dondale, 1990), and Quebec (e.g., Bélanger and Hutchinson, 1992). However, in such studies the Arctic components were not a primary focus.

Reports focused on Arctic Nearctic spiders are scarce. Of these, some were primarily taxonomic, e.g., Saaristo and Koponen (1998) on Agyneta and Buckle and Redner
(1964) on the Xysticus labradorensis subgroup. Other reports where the focus was not primarily taxonomic were based on small numbers of specimens. For example, Jackson $(1933,1938)$ reported 122 specimens from Akpatok Island, Ungava Bay, and 25 specimens from northeastern Baffin Island; Hillyard (1979) reported 29 adults from southern Baffin Island and Greenland; and McAlpine (1965) reported two specimens of one species (but numerous of another) from Ellef Ringnes Island. There are few reports of large collections of Arctic Nearctic spiders (excluding Greenland). Leech (1966) dealt with about 20000 specimens from Hazen Camp, Ellesmere Island, Nunavut; Leech and Ryan (1972) reported 2375 specimens from Devon Island, Nunavut; and Koponen (1992) reported 1065 identifiable specimens from the Belcher Islands, Hudson Bay, Nunavut.

Reports of large collections from the Arctic are valuable because they record changes in the range of species, bring to light intermediate forms of geographically separated species or subspecies, report new taxa, provide biogeographical snapshots of defined taxa, and in general contribute to our understanding of biodiversity changes in a time of anthropogenic changes to ecosystems (Chapin and Körner, 1994). Therefore, the opportunity to make a

${ }^{1}$ Biology Department, Memorial University of Newfoundland, Newfoundland and Labrador A1B 3X9, Canada; rpickava@ mun.ca (C) The Arctic Institute of North America 
major collection of Arctic spiders was particularly welcome.

In 1997, the Canadian Wildlife Service started a longterm study under the general direction of Dr. H.G. Gilchrist (National Wildlife Research Centre, Ottawa) of marine birds breeding in the East Bay Migratory Bird Sanctuary (Southampton Island, Nunavut, Canada). As part of this study, Mr. I.J. Stenhouse (Memorial University of Newfoundland, St. John's) investigated the reproductive ecology of Sabine's gull, Xema sabini (Sabine), which is a pelagic feeder for much of the year (Stenhouse, 2003). During the early breeding season of this species, ice prevents open-water feeding near the nesting area, so it was hypothesized that terrestrial arthropods might become a food source. Reports of Arctic-breeding birds (including Sabine's gull) feeding on terrestrial arthropods, including spiders (Sutton, 1932; Danks, 1971; Day et al., 2001), support this hypothesis. A successful pilot study of the terrestrial arthropods in 1999 led to a full-scale pitfalltrapping programme in 2000 and 2001. Spiders from the latter two years are the subjects of this paper.

\section{METHODS}

Southampton Island lies immediately south of the Arctic Circle in the mouth of Hudson Bay, Canada, extending approximately from $63^{\circ}$ to $66^{\circ} \mathrm{N}$ and from $80^{\circ}$ to $87^{\circ} \mathrm{W}$. The south and west of the Island are in the Southern Arctic Ecozone, while the northeast and east are part of the Northern Arctic Ecozone because of the strong influence of the cold, deep Foxe Channel to the northeast.

The East Bay Migratory Bird Sanctuary is a $1200 \mathrm{~km}^{2}$ area centred on approximately $64^{\circ} \mathrm{N}, 82^{\circ} \mathrm{W}$ in the Wager Bay Ecoregion within the Northern Arctic Ecozone. In general, this ecoregion is characterized by lichen-covered rock outcrops; discontinuous tundra vegetation of dwarf birch (Betula), willow (Salix), Labrador tea (Ledum), mountain avens (Dryas) and bilberry (Vaccinium); and wet areas dominated by willow and sedges (Carex). Permafrost is continuous, with low ice content. Mean annual temperature is about $-11^{\circ} \mathrm{C}$, summer and winter means are $+4.5^{\circ} \mathrm{C}$ and $-26.5^{\circ} \mathrm{C}$ respectively, and mean annual precipitation is about $200-300 \mathrm{~mm}$ (Ecological Stratification Working Group, 1995).

The site of this study was a $2 \times 2.5 \mathrm{~km}$ area of low-lying, coastal wetland tundra with a complex of brackish and freshwater ponds on the southern shore of the East Bay Migratory Bird Sanctuary. In general, the drier parts are characterized by dwarf shrubs (particularly willow) and mountain avens, and the wetter areas by mosses, sedges, and grasses.

Within the study site, six habitats were distinguished on the basis of vegetation: gravel ridge, dry heath, scrub willow, sedge meadow, moss carpet, and intertidal zone (Table 1). In addition, 13 types of sub-habitat were distinguished, representing variations within the habitats
(Table 1). In 2000, a total of 130 traps were set at $4 \mathrm{~m}$ intervals along transects in the western part of the study site, a set of 10 in each type of sub-habitat. In 2001, another 130 traps were set in a similar fashion, but 5 of each set of 10 traps were placed in the western part of the site and 5 in the eastern part, with one exception. The scrub willow subhabitat did not exist in the east, so all 10 traps were placed in the west (Table 2).

Pitfall traps in this study were plastic tubs about $11 \mathrm{~cm}$ (top diameter) by $8 \mathrm{~cm}$ (bottom diameter) by $8 \mathrm{~cm}$ (depth), with about $1 \mathrm{~cm}$ of propylene glycol (without detergent) in the bottom of each. Traps were left a full seven days before being emptied, and were emptied three times in 2000 (on 8,16 , and 24 July) and four times in 2001 (on 29 June; 7 , 15 , and 23 July). Trap contents were strained through a $0.01 \mathrm{~mm}$ mesh and transferred to ethanol.

\section{RESULTS}

The total of 22816 spiders caught comprised 4105 immatures, assigned only to family or genus, and 18711 adults, either identified to species or designated as unknown. Specimens with their original field-assigned numbers (T- ; see Table 2) are archived in the Biology Department Collection, Memorial University of Newfoundland (access title: Southampton 2000/2001).

Linyphiid nomenclature in this paper follows Buckle et al. (2001). A summary of species and numbers caught in both years is presented in Table 3. For this summary, the contents of the 5 or 10 traps from each habitat or subhabitat (Table 2) are pooled, and sexes are combined because sexual differences are not a primary focus here. In addition, sub-habitats are combined because comparisons of numbers of adult spiders caught in each sub-habitat by a series of independent samples t-tests and a single oneway analysis of variance indicated no significant differences for any of the comparisons. East and west sets of traps in 2001 are also combined because an independent samples t-test indicated no significant difference between the east and west samples in number of adult spiders caught.

When numbers of adults of each species are expressed in terms of habitats where they were caught (Table 4), samples from 2000 and 2001 are combined because an independent samples t-test indicated no significant difference between the numbers of adult spiders caught in the two years. "Majority preference" is defined here as the habitat, or at most two habitats, where more than $50 \%$ of the specimens of one species were caught. All species seem to share habitats to some extent, and with the single exception of the intertidal zone, no single habitat is clearly dominated by one species (note that here "intertidal" refers to land within the storm splash zone (Table 1) rather than land that is sea-covered twice a day). Overwhelmingly, but not exclusively, the intertidal zone is occupied by Erigone psychrophila, although this species shares its 
TABLE 1. Characteristics of the six habitat types in the study site in East Bay Migratory Bird Sanctuary, Southampton Island, Nunavut, Canada (after Stenhouse, 2003).

\begin{tabular}{|c|c|}
\hline Habitat & Characteristics \\
\hline Gravel ridge & $\begin{array}{l}\text { Bare gravel with little vegetation; visibly higher than surrounding areas; sparsely colonized by mountain avens at the low edges; on } \\
\text { highest and driest parts, flora is restricted to a few herbs and lichens. }\end{array}$ \\
\hline Dry heath & $\begin{array}{l}\text { Relief varies from relatively flat to hummocked; typical in drier areas farther from shore; ericaceous shrubs are dominant, with extensive } \\
\text { mountain avens; some willows; abundant lichens; herbs moderate in richness and abundance; substrate is a variable mixture of soil, rock, } \\
\text { and gravel. }\end{array}$ \\
\hline Scrub willow & $\begin{array}{l}\text { Typical in drier areas near shore; willow is one of the dominant plants; herbs, grasses, sedges, and lichens are also present; substrate is } \\
\text { largely exposed soil with rocks of various sizes, but mostly less than } 30 \mathrm{~cm} \text {. }\end{array}$ \\
\hline Moss carpet & $\begin{array}{l}\text { Typical of pond edges in areas between inland and littoral habitats; moss covers the substrate; sedges and grasses are sparsely to } \\
\text { moderately abundant; herbs are patchy and sparse, but numerous species are present. }\end{array}$ \\
\hline Intertidal zone & Within splash range of fall storms; moss and grasses are sparse and patchy; dead moss forms an organic crust of moderate abundance. \\
\hline Sedge meadow & $\begin{array}{l}\text { Relief varies from flat to hummocked; typical in moist areas and pond edges far from shore; moss covers substrate; sedges and grasses } \\
\text { are tall and dense; herbs are abundant and diverse; few rocks are present. }\end{array}$ \\
\hline
\end{tabular}

TABLE 2. Placement (Habitat, Sub-habitat), numbering (T) and number (\#) of pitfall traps in 2000 and 2001 in the six habitat types and 13 sub-habitats in the study site in East Bay Migratory Bird Sanctuary, Southampton Island, Nunavut, Canada (after Stenhouse, 2003).

\begin{tabular}{|c|c|c|c|c|}
\hline Habitat & Sub-habitat & 2000 West (\#) & 2001 West (\#) & 2001 East (\#) \\
\hline \multirow[t]{2}{*}{ Gravel ridge } & Bare & $\mathrm{T} 1(10)$ & $\mathrm{T} 1(5)$ & $\mathrm{T} 13 \mathrm{~A}(5)$ \\
\hline & Vegetated & T 2 (10) & T 2 (5) & T 13B (5) \\
\hline \multirow[t]{2}{*}{ Dry heath } & Flat & T 3 (10) & T $3(5)$ & $\mathrm{T} 14(5)$ \\
\hline & Hummocked & $\mathrm{T} 4(10)$ & $\mathrm{T} 4(5)$ & $\mathrm{T} 15(5)$ \\
\hline \multirow[t]{2}{*}{ Scrub willow } & South & T 5 (10) & T $5(5)$ & T $16(5)$ \\
\hline & North & T 6 (10) & T 6 (10) & none \\
\hline \multirow[t]{3}{*}{ Moss carpet } & A: south of nests & T 7 (10) & Т 7 (5) & T $19(5)$ \\
\hline & B1: gull area; not by nest & T 8 (10) & T 8 (5) & T $17(5)$ \\
\hline & B2: gull area: near nest & T 9 (10) & T $9(5)$ & T $18(5)$ \\
\hline \multirow[t]{2}{*}{ Intertidal zone } & No vegetation & T 10A (10) & T 10A (5) & T $20 \mathrm{~A}$ \\
\hline & Vegetated & $\mathrm{T} 10 \mathrm{~B}(10)$ & T 10B (5) & T 20B (5) \\
\hline \multirow[t]{2}{*}{ Sedge meadow } & Flat & T 11A (10) & T 11A (5) & T 12A (5) \\
\hline & Hummocked & T 11B (10) & $\mathrm{T} 11 \mathrm{~B}(5)$ & $\mathrm{T} 12 \mathrm{~B}(5)$ \\
\hline
\end{tabular}

secondary majority preference habitat (moss) with other species.

It is clear that many species have similar habitats, as defined by majority preference, e.g., both Halorates thulensis and Diplocephalus barbiger prefer gravel and heath, Hybauchenidium aquilonare and Hilaira vexatrix prefer heath, and Hilaira proletaria and Halorates holmgrenii prefer sedge. Other examples will be obvious from Table 4. Species occupying the same habitat are assumed to be occupying different ecological niches by partitioning some resource other than the habitat. Adult lycosids and adult linyphiids occupying the same habitat are not considered to occupy the same niche because of size differences.

Co-generic species frequently have similar niches and often reduce competition by partitioning the habitat. This is the case for Alopecosa, Erigone, Halorates, and Hilaira, which demonstrate clear habitat partitioning between the two species of each genus. This does not seem to be the case for Pardosa algens and P. glacialis, both of which have a majority preference for heath and sedge. However, since only six $P$. glacialis were caught, this similarity may be an artefact of sampling or may really indicate that other factors must account for the coexistence of these two species.

\section{DISCUSSION}

\section{Comparison of Numbers of Families and Species}

Table 5 compares the numbers of spider families and species reported from six Arctic Nearctic localities arranged by decreasing latitude from left to right. Greenland is omitted because its spider record refers to the whole island, whereas all six Canadian records are from one more 
TABLE 3. Summary of spiders caught in 2000 and 2001 in the study site in East Bay Migratory Bird Sanctuary, Southampton Island, Nunavut, Canada.

\begin{tabular}{|c|c|c|c|c|c|c|}
\hline & \multicolumn{3}{|c|}{2000} & \multicolumn{3}{|c|}{2001} \\
\hline & Male & Female & Immature & Male & Female & Immature \\
\hline \multicolumn{7}{|l|}{ Lycosidae } \\
\hline Alopecosa exasperans (O. P.-Cambridge) & 170 & 24 & & 214 & 32 & \\
\hline Alopecosa hirtipes (Kulczynski) & 1 & 0 & & 3 & 0 & \\
\hline Immature Alopecosa & & & 70 & & & 53 \\
\hline Pardosa algens (Kulczynski) & 291 & 79 & & 226 & 75 & \\
\hline Pardosa glacialis (Thorell) & 3 & 0 & & 2 & 1 & \\
\hline Immature Pardosa & & & 126 & & & 156 \\
\hline \multicolumn{7}{|l|}{ Linyphiidae } \\
\hline Agyneta maritima (Emerton) & 5 & 42 & & 2 & 17 & \\
\hline Arcterigone pilifrons $(\mathrm{L}$. Koch) & 8 & 8 & & 11 & 27 & \\
\hline Diplocephalus barbiger (Roewer) & 0 & 1 & & 4 & 3 & \\
\hline Erigone arctica White in Sutherland & 3437 & 2448 & & 2159 & 1111 & \\
\hline Erigone psychrophila Thorell & 2178 & 1764 & & 1952 & 1469 & \\
\hline Halorates holmgrenii (Thorell) & 7 & 1 & & 26 & 2 & \\
\hline Halorates thulensis (Jackson) & 13 & 10 & & 40 & 12 & \\
\hline Hilaira proletaria (L. Koch) & 26 & 0 & & 8 & 4 & \\
\hline Hilaira vexatrix (O. P.-Cambridge) & 15 & 34 & & 27 & 10 & \\
\hline Hybauchenidium aquilonare (L. Koch) & 5 & 35 & & 22 & 41 & \\
\hline Oreoneta brunnea (Emerton) & 70 & 24 & & 55 & 9 & \\
\hline Silometopoides pampia (Chamberlin) & 10 & 55 & & 3 & 39 & \\
\hline Unknown erigonine linyphiid sp. \#1 & 65 & 78 & & 61 & 73 & \\
\hline Unknown erigonine linyphiid sp. \#2 & 6 & 18 & & 14 & 26 & \\
\hline Immature Linyphiidae & & & 1497 & & & 2203 \\
\hline Yearly Subtotals & 6310 & 4621 & 1693 & 4829 & 2951 & 2412 \\
\hline Total by year, all adults: & \multicolumn{3}{|c|}{10931} & \multicolumn{2}{|c|}{7780} & \\
\hline Total by year, all spiders: & & 12624 & & & 10192 & \\
\hline Total, both years combined, all spiders: & & & & & & \\
\hline
\end{tabular}

TABLE 4. Total numbers of adults ${ }^{1}$ of each species caught in each habitat ${ }^{2}$ in East Bay Migratory Bird Sanctuary, Southampton Island, Nunavut, Canada.

\begin{tabular}{|c|c|c|c|c|c|c|}
\hline & \multicolumn{6}{|c|}{ Habitats } \\
\hline & Gravel & Heath & Intertidal & Moss & Sedge & Willow \\
\hline \multicolumn{7}{|l|}{ Lycosidae } \\
\hline Alopecosa exasperans & 224 & 123 & 0 & 3 & 90 & 0 \\
\hline Alopecosa hirtipes & 0 & 1 & 0 & 1 & 0 & 2 \\
\hline Pardosa algens & 13 & 363 & 0 & 50 & 228 & 17 \\
\hline Pardosa glacialis & 0 & 3 & 0 & 1 & 2 & 0 \\
\hline \multicolumn{7}{|l|}{ Linyphiidae } \\
\hline Agyneta maritima & 36 & 0 & 0 & 0 & 29 & 1 \\
\hline Arcterigone pilifrons & 0 & 6 & 1 & 16 & 5 & 26 \\
\hline Diplocephalus barbiger & 5 & 3 & 0 & 0 & 0 & 0 \\
\hline Erigone arctica & 306 & 2239 & 70 & 2109 & 757 & 3674 \\
\hline Erigone psychrophila & 16 & 125 & 2420 & 2291 & 1922 & 589 \\
\hline Halorates holmgrenii & 1 & 4 & 0 & 3 & 21 & 7 \\
\hline Halorates thulensis & 43 & 26 & 0 & 2 & 4 & 0 \\
\hline Hilaira proletaria & 0 & 0 & 0 & 0 & 37 & 1 \\
\hline Hilaira vexatrix & 0 & 56 & 0 & 4 & 10 & 16 \\
\hline Hybauchenidium aquilonare & 5 & 94 & 0 & 0 & 2 & 2 \\
\hline Oreoneta brunnea & 1 & 27 & 0 & 91 & 0 & 39 \\
\hline Silometopoides pampia & 0 & 38 & 0 & 11 & 40 & 18 \\
\hline Unknown linyphiid sp. \#1 & 1 & 5 & 2 & 112 & 108 & 49 \\
\hline Unknown linyphiid sp. \#2 & 0 & 2 & 0 & 17 & 38 & 7 \\
\hline
\end{tabular}

${ }^{1}$ Sexes, sub-habitats, west and east traps, and years combined.

${ }^{2}$ See Tables 1 and 2 for habitat names and characteristics.

or less well-defined area of a larger land mass. Data sources are indicated in parentheses: Hazen Camp, Ellesmere Island (Leech, 1966); Devon Island (Leech and
Ryan, 1972); Baffin Island (combined from Hillyard, 1979 and Jackson, 1938); Akpatok Island (Jackson, 1933); Belcher Islands (Koponen, 1992). 
TABLE 5. Number of spider families and species in six Canadian Arctic localities.

\begin{tabular}{lcccccc}
\hline \hline Place & Hazen Camp & Devon Island & Baffin Island & $\begin{array}{c}\text { East Bay, } \\
\text { Southampton Island }\end{array}$ & Akpatok Island & Belcher Islands \\
\hline Latitude North & $82^{\circ}$ & $76^{\circ}$ & $66,71^{\circ}$ & $64^{\circ}$ & $60^{\circ}$ & $56^{\circ}$ \\
Number of specimens & 20600 & 2375 & 65 & 22816 & 125 & 19 \\
Total species: & 13 & 8 & 10 & 2 & $31^{2}$ & 8 \\
Total families & 4 & 2 & 2 & 2 & 3 & \\
\hline \hline
\end{tabular}

${ }^{1}$ Devon Island, Southampton Island, Hazen Camp, and Akpatok Island: total numbers include immature specimens; for Baffin Island and the Belcher Islands, numbers are adults only.

${ }^{2}$ Koponen (1992) reported 33 species from the Belcher Islands, but synonymies reduce this number to 31.

TABLE 6. Patchiness of distribution of Arctic Nearctic spiders over six Canadian locations.

\begin{tabular}{cccccccc}
\hline \hline \multirow{2}{*}{ Number of Places } & & \multicolumn{5}{c}{ Number (and \%) $)^{1}$ of Species Common to } \\
\cline { 3 - 6 } & Total Species & 1 Place & 2 Places & 3 Places & 4 Places & 5 Places & 6 Places \\
\hline $6^{2}$ & 55 & $28(51 \%)$ & $17(31 \%)$ & $6(11 \%)$ & $3(6 \%)$ & $1(2 \%)$ & 0 \\
\hline \hline
\end{tabular}

${ }^{1}$ Percent values rounded to whole number.

${ }^{2}$ Hazen Camp, Devon Island, Baffin Island, Southampton Island, Akpatok Island, Belcher Islands.

Generally in the Northern Hemisphere, the numbers of spider families and species decrease with increasing latitude until, for example, the most northern spider fauna in the world (on Peary Land, Greenland, c. $82.5^{\circ} \mathrm{N}$ ) has only three families and seven species (excluding for present purposes the introduced agelenid Tegenaria domestica) (Braendegaard, 1960). For the Canadian locations listed in Table 5, this pattern holds true except for the most northerly location, Hazen Camp, which has both more families (4) than any place except Belcher, and more species (13) than Devon or Baffin. Only larger samples collected by uniform methods will establish whether this discrepancy is an artefact of sampling or a true reflection of local conditions that favour the spider community.

\section{Patchiness of the Arctic Nearctic Spider Fauna}

At one level the Arctic can be seen as an essentially uniform biome in which species will be widely distributed. For example, Porsild (1957:6), referring to the Arctic flora, said that "the monotonous topography of large parts of the Arctic Archipelago and its uniformly cold, dry climate are reflected in the general appearance of the plant cover, which shows little variation from place to place." However, for spiders the opposite has been reported: e.g., Hillyard (1979) noted that of the 8 species from Baffin and 12 from Greenland that he reported, not one was found in both localities, and Leech and Ryan (1972) found it striking that so few of the species reported from either Hazen Camp or west Greenland were found at Truelove Inlet, Devon Island.

This patchiness of distribution of Arctic Nearctic spider species is clearly shown in Table 6. Data sources for Table 6 are those identified above for Table 5. It is noteworthy that of the collective 55 species counted for all six locations, over $50 \%$ of species are found in only one location, $90 \%$ occur in half or fewer of the locations, and not one is found at all six locations.

Note that even when the two small samples (Baffin and Akpatok; see Table 5) are ignored, the same patchiness is shown by the other four large (1000+) samples, so in this particular case the phenomenon is likely not simply a sampling artefact. This raises interesting questions. Is this patchiness a result of dispersion difficulties in the Arctic? Or a reflection of localized habitat and microclimate differences that favour different species in different places? Or does it reflect other factors or a combination of factors? Porsild (1957:6) does point out that within the general uniformity of the Arctic Archipelago, “... in the east the mountainous topography provides more local variety and more diversified plant habitats." More detailed studies are needed to address these questions.

\section{Comparison of Habitat Preferences}

Comparing reports of habitat preferences of Arctic spiders is problematic because only two other reports deal with this subject in any detail, and each used a different way of describing habitat preferences. Koponen (1992) grouped his 15 different sampling sites into three categories-dry (eight sites), mesic (three sites), and moist (four sites)—and assigned each Belcher Islands spider species to one of these categories. Leech (1966) assigned each Hazen Camp spider species to one of three ecological types: arid, euryecious, or humid. How far the latter three categories correspond to the former three is uncertain.

In the present study, three sites (gravel, heath, willow) can be considered dry, and three (moss, intertidal, sedge) can be considered moist or humid (Table 1). Habitat preference of a species is defined by the location where a 
majority of its specimens were caught (Table 4). For three species, there is agreement between this study and the reports of Koponen (1992) and Leech (1966): E. psychrophila likes moist areas, Alopecosa exasperans likes dry areas, and Pardosa glacialis likes mixed areas. Preferences of other species seem to differ: Alopecosa hirtipes, Agyneta maritima, Erigone arctica, Hilaira vexatrix, and Silometopoides pampia prefer mixed areas on Southampton Island but either moist or dry areas elsewhere; Diplocephalus barbiger and Halorates thulensis prefer dry areas on Southampton Island but moist areas elsewhere, and Oreoneta brunnea and Halorates holmgrenii prefer moist areas on Southampton Island but dry areas elsewhere.

But all these apparent matches or mismatches are suspect because of small numbers of some species (e.g., only four Alopecosa hirtipes in the present study), the problems of defining habitat at the microhabitat level relevant to Arctic spiders, and the particular difficulty of comparing habitats across different reports. Any deeper analysis must wait until standardized criteria can be employed and large numbers of each species can be compared.

\section{ACKNOWLEDGEMENTS}

I am very grateful to the Canadian Wildlife Service in general and to Dr. H.G. Gilchrist (National Wildlife Research Centre, Ottawa) in particular; his interest and generosity made this study possible. My thanks are due to Dr. I.J. Stenhouse, who as a doctoral student at Memorial University enthusiastically undertook the fieldwork involved, and to his supervisors Dr. H.G. Gilchrist and Dr. W.A. Montevecchi (Memorial University of Newfoundland) who supported the fieldwork. I am grateful for the significant help in the field provided by Mr. P. Smith. I thank Dr. C.D. Dondale (Canadian National Collection of Insects and Arachnids, Agriculture and Agri-foods Canada, Ottawa) for his usual generous assistance with questions involving Canadian spiders, and Dr. M. Courage (Memorial University of Newfoundland) for significant statistical advice.

\section{REFERENCES}

AITCHISON-BENELL, C.W., and DONDALE, C.D. 1990. A checklist of Manitoba spiders (Araneae) with notes on geographic relationships. Le Naturaliste Canadien 117(4):215237.

BÉLANGER, G., and HUTCHINSON, R. 1992. Liste annotée des araignées (Araneae) du Québec. Pirata 1:2-119.

BRAENDEGAARD, J. 1960. The spiders of Peary Land, North Greenland. Meddelelser om Grønland 159(6):3-24.

BUCKLE, D.J., and REDNER, J.H. 1964. The Nearctic species of the Xysticus labradorensis subgroup (Araneae: Thomisidae). The Canadian Entomologist 96:1138-1142.

BUCKLE, D.J., CARROLL, D., CRAWFORD, R.L., and ROTH, V.D. 2001. Linyphiidae and Pimoidae of America north of
Mexico: Checklist, synonymy, and literature. In: Paquin, P., and Buckle, D.J., eds. Contributions à la connaissance des Araignées (Araneae) d'Amérique du Nord. Fabreries Supplément 10, Part 2:89-191.

CHAPIN, F.S., and KÖRNER, C. 1994. Arctic and alpine biodiversity: Patterns, causes and ecosystem consequences. Trends in Ecology and Evolution 9:45-47.

DANKS, H.V. 1971. A note on the early season food of Arctic migrants. Canadian Field-Naturalist 85:71-72.

DAY, R.H., STENHOUSE, I.J., and GILCHRIST, H.G. 2001. Sabine's gull (Xema sabini). In: Poole, A., and Gill, F., eds. The birds of North America, No. 593. Philadelphia, Pennsylvania: The Birds of North America, Inc.

DONDALE, C.D., REDNER, J.H., and MARUSIK, Y.M. 1997. Spiders (Araneae) of the Yukon. In: Danks, H.V., and Downes, J.A., eds. Insects of the Yukon. Ottawa: Biological Survey of Canada (Terrestrial Arthropods). 73-113.

ECOLOGICAL STRATIFICATION WORKING GROUP. 1995. A national ecological framework for Canada. Ottawa: Agriculture and Agri-Food Canada, Research Branch, Centre for Land and Biological Resources Research and Environment Canada, State of the Environment Directorate, Ecozone Analysis Branch.

ESKOV, K.Y. 1987. Spiders of Nearctic genera Ceraticelus and Islandiana (Aranei, Linyphiidae) in the fauna of Siberia and the Far East. Zoologicheskii Zhurnal 66:1748-1752.

1989. The spider genus Collinsia O. Pickard-Cambridge 1913 in the fauna of Siberia and the Soviet Far East (Arachnida: Araneae: Linyphiidae). Senckenbergiana Biologica 70(4-6): 287-298.

HILLYARD, P.D. 1979. Notes on two collections of spiders from Baffin Island and Greenland. Bulletin of the British Arachnological Society 4(7):296-297.

JACKSON, A.R. 1933. Results of the Oxford University expedition to Akpatok in 1931. Proceedings of the Zoological Society of London 1933(1):145-159.

— 1938. Notes on Arctic spiders obtained in 1933-1936. Proceedings of the Zoological Society of London 107B(4): 543-561.

KOPONEN, S. 1975. Spider populations in a subalpine birch forest. In: Wielgolaski, F.E., ed. Ecological studies: Analysis and synthesis, Vol. 17. Fennoscandian Tundra Ecosystems, Part 2:66-72.

- 1977. Spider fauna (Araneae) of Kevo area, northernmost Finland. Report of the Kevo Subarctic Research Station 13: $48-62$.

. 1980. Spider fauna in Adventfjorden area, Spitsbergen. Report of the Kevo Subarctic Research Station 16:13-16.

- 1992. Spider fauna (Araneae) of the low Arctic Belcher Islands, Hudson Bay. Arctic 45(4):358-362.

KOPONEN, S., MARUSIK, Y.M., and TANASEVITCH, A.V. 1998. New data on the spider fauna of the Polar Urals (Aranei). Arthropoda Selecta 6:109-119.

LARSEN, S., and SCHARFF, N. 2003. The spiders of Greenland: A checklist (Arachnida; Araneae). Entomologiske Meddelelser $71: 53-61$.

LEECH, R.E. 1966. The spiders (Araneida) of Hazen Camp 81 ${ }^{\circ} 49^{\prime}$ N, $71^{\circ} 18^{\prime} \mathrm{W}$. Quaestiones Entomologicae 2:153-212. 
LEECH, R.E., and RYAN, J.K. 1972. Notes on Canadian Arctic spiders (Araneida), mainly from Devon Island, NWT. Canadian Entomologist 104:1787-1791.

MARUSIK, Y.M., KOPONEN, S., and POTAPOVA, N.K. 2004. Spiders (Aranei) from Oymyakon, the cold pole of the Northern Hemisphere (Yakutia, Siberia). Arthropoda Selecta 13:69-75.

McALPINE, J.F. 1965. Insects and related terrestrial invertebrates of Ellef Ringnes Island. Arctic 18(2):73-103.

PORSILD, A.E. 1957. Illustrated flora of the Canadian Arctic Archipelago. Bulletin No. 146. Ottawa: National Museum of Canada. 209 p.

SAARISTO, M.I., and KOPONEN, S. 1998. A review of northern Canadian spiders of the genus Agyneta (Araneae, Linyphiidae), with descriptions of two new species. Canadian Journal of Zoology 76:566-583.

SAARISTO, M.I., and MARUSIK, Y.M. 2004. Revision of the Holarctic spider genus Oreoneta Kulczyński, 1894 (Arachnida: Aranei: Linyphiidae). Arthropoda Selecta 12 (3-4):207-249.
STENHOUSE, I. 2003. The reproductive behaviour and ecology of Sabine's gull (Xema sabini) in the eastern Canadian Arctic. PhD Thesis, Memorial University of Newfoundland, St. John's, Newfoundland.

SUTTON, G.M. 1932. The exploration of Southampton Island, Hudson Bay. Memoirs of the Carnegie Museum 12:3-268.

TANASEVITCH, A.V. 1982. New genus and species of spiders of the family Linyphiidae (Aranei) from the Bolshezemelskaya Tundra. Zoologicheskii Zhurnal 61(10):1501-1508.

. 1983. New genera and species of spiders of the family Linyphiidae from the Polar Urals. Zoologicheskii Zhurnal 62(2):215-221.

- 1984. New and little known spiders of the family Linyphiidae (Aranei) from Bolshezemelskaya Tundra. Zoologicheskii Zhurnal 63(3):382-391.

- 1985. A study of spiders (Aranei) of the Polar Urals. Proceedings of the Zoological Institute, Leningrad 139:52-62. 